\title{
Theoretical Analysis of the Contact Area between Grinding Wheel Surface and Workpiece in Flat Face Grinding with Spindle Axis Inclination
}

\author{
János Kundrák ${ }^{1}$, Vladimir Fedorovich ${ }^{2}$, Ivan Pyzhov ${ }^{2}$, Angelos P. Markopoulos ${ }^{3}$, Vitaly Klimenko ${ }^{4}$, Natalya Kryukova ${ }^{2}$ \\ ${ }^{1}$ Institute of Manufacturing Science, University of Miskolc, Egyetemváros H-3515 Miskolc, Hungary. E-mail: \\ kundrak@uni-miskolc.hury \\ ${ }^{2}$ Department of Integrated Engineering Techniques n.a. M.F.Semko, National Technical University "Kharkiv Polytechnic \\ Institute", Kharkov, Ukraine. E-mail: fedorovich@kpi.kharkov.ua \\ ${ }^{3}$ Section of Manufacturing Technology, School of Mechanical Engineering, National Technical University of Athens, \\ Heroon Polytechniou 9, 15780 Athens, Greece. E-mail: amark@mail.ntua.gr \\ ${ }^{4}$ Department of Manufacturing Engineering, National Technical University, Poltava, Ukraine.
}

Theoretical analysis has been carried out for the determination of the analytical dependences connecting various parameters of contact area between wheel cutting surface and workpiece, such as length, width and arc length in the case of flat face grinding with preliminary inclination of spindle axis. The role of factors, such as angle of preliminary inclination of the spindle axis, grinding depth and grinding wheel diameter, in this process, are established. The capability to define the above mentioned parameters permits the calculation of the contact area between wheel cutting surface and workpiece. In addition, with the proposed methodology, it is possible to correctly determine the value of cross-feed, in the case of multiple-pass processing scheme, which, as it is known, should be consistent with the value of contact width of wheel cutting surface with workpiece. It can be guaranteed that on the ground surface there will be no areas unaffected by the wheel. In the case of through-feed grinding the obtained theoretical dependences make it possible to determine the processing conditions, taking into account the allowable value of flatness deviation. Finally, the latter, contributes in improving flat face grinding process and thus expanding its technological capabilities.

Keywords: wheel cutting surface, contact area, spindle axis inclination, grinding depth, wheel diameter

\section{Acknowledgements}

The authors greatly appreciate the support of the National Research, Development and Innovation Office - NKFIH (No. of Agreement: OTKA K 116876).

The described article/presentation/study was carried out as part of the EFOP-3.6.1-16-00011 "Younger and Renewing University - Innovative Knowledge City - institutional development of the University of Miskolc aiming at intelligent specialisation" project implemented in the framework of the Szechenyi 2020 program. The realization of this project is supported by the European Union, co-financed by the European Social Fund.

\section{References}

[1] NOVAK, M. (2012). Surfaces with high precision of roughness after grinding. Manufacturing Technology. 12, 66-70.

[2] LATTNER, R., HOLEŠOVSKÝ, F., KAREL, T., LATTNER, M. (2015). Abrasive Machining of Ti6Al4V Alloy. Manufacturing Technology. 15(4), 571-575.

[3] TOENSHOFF, H.K., DENKENA, B. (2013). Basics of Cutting and Abrasive Processes. Berlin Heidelberg: Springer-Verlag.

[4] LURIE, G.B., KOMISSARZHEVSKAYA, V.N. (1972). Grinding machines and their setting-up. Moscow: Higher school (In Russian).

[5] LOSKUTOV, V.V. (1976). Grinding machines. Moscow: Mechanical Engineering (In Russian).

[6] NAERMAN, M.S. (1985). Handbook of Young Grinder. Moscow: Higher School (in Russian).

[7] KLOCKE, F. (2009). Manufacturing Processes 2: Grinding, Honing, Lapping. Berlin Heidelberg: Springer-Verlag.

[8] KLIMENKO, V.G., PYZHOV, I.M. (2013). Improvement of flat face grinding process. High Technologies in Mechanical Engineering: Collected Scientific Papers. 23, 68-79 (In Ukrainian).

[9] PYZHOV, I.M., KLIMENKO, V.G. (2015). Research of contact width between wheel cutting surface and workpiece at flat face grinding with inclination of spindle axis. Journal of Engineering Sciences: Scientific Journal. 2(1), A10-A15 (In Ukrainian). 
[10] PYZHOV, I.M., KLIMENKO, V.G. (2015). Research of contact area between wheel cutting surface and workpiece at flat face grinding with preliminary inclination of spindle axis. Journal of Engineering Sciences: Scientific Journal. 2(2), A1-A6 (In Ukrainian).

[11] NAKAO, M., HATAMURA, Y. (1996). Development of an Intelligent Face Grinding Machine to Fabricate U1traflat Surfaces on Thin, Brittle Substrates. Annals of the CIRP. 45(1), 397-400.

[12] ZHONG, Z. (1992). New Grinding Methods for Aspheric Mirrors with Large Curvature Radii. Annals of the CIRP. 41(1), 335-338.

[13] ZHONG, Z., VENKATESH, V. C. (1994). Generation of Parabolic and Toroidal Surfaces on Silicon and SiliconEased Compounds Using Diamond Cup Grinding Wheels. Annals of the CIRP. 43(1), 323-326.

[14] CHEN, W.K., HUANG, H. (2003). Ultra precision grinding of spherical convex surfaces on combination brittle materials using resin and metal bond cup wheels. Journal of Materials Processing Technology. 140, $217-223$.

[15] YIN, S., WANG, J., CHEN, F., JIANWU, Y., WANG, Y., ZHAO, Q., LI, H. (2011). Inclined Axis Ultra-Precision Grinding for Spherical Surface. Solid State Phenomena. 175, 145-149.

[16] HUO, F.W., GUO, D.M., FENG, G., KANG, R.K., WANG, R.L. (2012). A new kinematics for ultra precision grinding of conical surfaces using a rotary table and a cup wheel. International Journal of Machine Tools \& Manufacture. 59, 34-45.

[17] SHIHA, A.J., LEE, N.L. (1999). Precision cylindrical face grinding. Precision Engineering. 23(3), $177-184$.

[18] SUN, W., PEI, Z.J., FISHER, G.R. (2005). Fine grinding of silicon wafers: machine configurations for spindle angle adjustments. International Journal of Machine Tools \& Manufacture. 45, 51-61.

[19] CHIANG, C.-J., FONG, Z.-H. (2009) Undercutting and interference for thread form grinding with a tilt angle. Mechanism and Machine Theory. 44, 2066-2078.

[20] HUO, F. GUO, D., LI, Z., FENG, G., KANG, R. (2013). Generation of rotationally symmetric surfaces by infeed grinding with a rotary table and a cup wheel. Precision Engineering, 37, 286- 298.

[21] FENG, G., HUO, F.W., JIN, Z.J., KANG, R.K., GUO, D.M. (2013). High-accuracy Calibration of the Wheel Spindle Tilt Angle for Grinding Hydrostatic Seal Rings Used in Reactor Coolant Pumps. Advanced Materials Research. 797, 140-145.

[22] UHLMANN, E., BORSOI KLEIN, T., KOPROWSKI, S. (2014). Tilt angle effects in surface grinding with mounted points. Production Engineering. 8, 431-442.

[23] ZHANG, Z.-X., FONG, Z.-H. (2015). A novel tilt form grinding method for the rotor of dry vacuum pump. Mechanism and Machine Theory. 90, 47-58.

[24] CHEN, F., YIN, S., HUANG, H., OHMORI, H. (2015). Fabrication of small aspheric moulds using single point inclined axis grinding. Precision Engineering. 39, 107-115.

[25] KUNDRÁK, J. FEDOROVICH, V., PYZHOV, I., MARKOPOUlOS, A., KLIMENKO, V. (2015). Some Features of the Surface Micro- and Macroprofile Formation at Flat Face Grinding with Spindle Axis Inclination. Applied Mechanics and Materials. 809-810, 45-50.

[26] ALEKSANDROV, P.S. (1968). Lectures on analytic geometry. Moscow: The publishing house of phisico-mathematical literature (In Russian).

[27] VYGODSKY, M. (2006). Mathematical handbook: Elementary mathematics. Moscow: Astrel' (In Russian). 